\title{
P01.12. Prophylactic effects of Lonicera japonica extract on dextran sulfate sodium-induced colitis in a mouse model by inhibition of the Th1/Th17 response
}

\author{
J Park, J Kim, B Ryu, S Ko, S Jongki, Y Bu \\ From International Research Congress on Integrative Medicine and Health 2012 \\ Portland, Oregon, USA. 15-18 May 2012
}

\section{Purpose}

Inflammatory bowel diseases (IBDs) are chronically relapsing inflammatory disorders of the intestine. Although some therapeutic agents, including steroids, are available for treatment of IBD, these agents have limited use. Therefore, dietary supplements have emerged as possible interventions for IBD. Japanese honeysuckle flower, the flower of Lonicera japonica, is a well-known dietary supplement and has been used to prevent or treat various inflammatory diseases.

\section{Methods}

In the current study, we investigated the effects of L. japonica on experimental murine colitis. Colitis was induced by $5 \%$ dextran sulfate sodium (DSS) in Balb/c mice. The water extract of L. japonica (LJE) at doses of 20,100 or $500 \mathrm{mg} / \mathrm{kg}$ was orally administered to the mice twice a day for 7 days. Body weight, colon length and a histological damage score were assessed to determine the effects on colitis. Cytokine profiles were assessed to examine the effects on T helper (Th) cellrelated immunological responses. In addition, $\mathrm{CD} 4+$ CD25 + FOXP3 T cells were analyzed in vivo and in vitro for investigating the effects on regulatory $\mathrm{T}\left(\mathrm{T}_{\mathrm{reg}}\right)$ cells.

\section{Results}

LJE showed dose-dependent inhibitory effects against colon shortening, weight loss and histological damage. LJE down-regulated interleukin (IL)- $1 \beta$, tumor necrosis factor $\alpha$, interferon $\gamma$, IL-6, IL-12 and IL-17. However,

College of Oriental Medicine, Kyung Hee University, Seoul, Republic of Korea
LJE did not show any significant effects on IL-10, IL-23, transforming growth factor $\beta 1$ and $\mathrm{T}_{\text {reg }}$ cell populations.

\section{Conclusion}

In conclusion, LJE showed protective effects against DSS-induced colitis via the Th1/Th17 pathway and not via $\mathrm{T}_{\text {reg }}$ cell-related mechanisms.

Published: 12 June 2012

doi:10.1186/1472-6882-12-S1-P12

Cite this article as: Park et al:: P01.12. Prophylactic effects of Lonicera japonica extract on dextran sulfate sodium-induced colitis in a mouse model by inhibition of the Th1/Th17 response. BMC Complementary and Alternative Medicine 2012 12(Suppl 1):P12.

Submit your next manuscript to BioMed Central and take full advantage of:

- Convenient online submission

- Thorough peer review

- No space constraints or color figure charges

- Immediate publication on acceptance

- Inclusion in PubMed, CAS, Scopus and Google Scholar

- Research which is freely available for redistribution 